\title{
Correlation of International and Russian National Law with Regard to Environmental Protection of the Caspian Sea
}

\author{
Araz O. Mursaliev* \\ Moscow State Institute of International Relations (University) \\ of the Ministry of Foreign Affairs of the Russian Federation \\ Moscow, Russian Federation
}

Received 13.05.2020, received in revised form 17.04.2021, accepted 30.04.2021

\begin{abstract}
In 2018, the legal status of the Caspian Sea was clearly defined. Hence, the issue of sustainable development takes the centre stage. Regional legal regime of environmental protection may develop through the transfer of executive functions provided for in the intergovernmental convention and entrusted to the national authorities of the Caspian States to a single competent authority in order to improve their efficiency. The article is aimed at studying the issues of correlation between international legal rules on the Caspian Sea environmental protection and Russian national legislation in order to identify the optimal scope of executive functions that can be transferred to a regional intergovernmental organization, as well as to identify promising directions for further development of the applicable national legislation. The author shows that for a more efficient environmental protection of the Caspian region the Caspian states need a single regional intergovernmental body that coordinates their environmental activities, collects data and information on pollution on a centralized and timely basis, and regularly performs assessment of the Caspian region environment. Further, the author also shows the need for further development of applicable national legislation in the context of the concept of integrated coastal management.
\end{abstract}

Keywords: international law, the Caspian Sea, environmental protection, national legislation, legal system, liability for damage, oil spills, runoff from rivers, basin management principle.

Research area: law.

Citation: Mursaliev, A.O. (2021). Correlation of international and Russian national law with regard to environmental protection of the Caspian Sea. J. Sib. Fed. Univ. Humanit. Soc. Sci., 14(5), 636-661. DOI: $10.17516 / 1997-1370-0748$.

\footnotetext{
(C) Siberian Federal University. All rights reserved

* Corresponding author E-mail address: mursaliev_a@bk.ru ORCID: 0000-0002-9358-7423
} 


\title{
Соотношение норм международного права
} и национального права Российской Федерации в отношении охраны окружающей среды Каспийского моря

\author{
A.0. Мурсалиев \\ Московский государственный институт \\ международных отношений (университет) \\ Министерства иностранных дел Российской Федеращии \\ Российская Федеращия, Москва
}

\begin{abstract}
Аннотация. С принятием Конвенции о правовом статусе Каспийского моря 2018 года правовой статус Каспийского моря был однозначно определен. В этой связи на первое место выходит проблематика устойчивого развития: имплементация норм по защите окружающей среды, исполнение реальных мероприятий и повышение их эффективности. Новым этапом развития регионального международноправового режима охраны окружающей среды может стать передача части исполнительных функций, предусмотренных межправительственной конвенцией и возложенных на национальные органы прикаспийских государств, на уровень единой компетентной организации для повышения их эффективности. Поставлена цель изучить вопросы соотношения международно-правовых норм об охране окружающей среды Каспийского моря и национального законодательства России для выявления оптимального объема исполнительных функций, которые могут быть переданы на уровень региональной межправительственной организации, а также выявить перспективные направления дальнейшего развития применимого национального законодательства. Показано, что, несмотря на детальность положений Тегеранской конвенции и протоколов к ней, для более эффективного осуществления охраны окружающей среды Каспийского региона прикаспийские государства нуждаются в единой региональной межправительственной организации для координации их природоохранной деятельности, централизованного и оперативного сбора данных и информации о загрязнениях, осуществления регулярной общерегиональной оценки состояния окружающей среды Каспийского региона. Также показана необходимость дальнейшего развития применимого национального законодательства в контексте концепции комплексного прибрежного управления. Сделан вывод, что международно-правовые нормы в отношении защиты окружающей среды Каспийского моря требуют обеспечения с точки зрения оперативного и эффективного исполнения, и даны рекомендации в отношении создания региональной межправительственной организации путем передачи ей части функций, отнесенных региональными соглашениями на национальный уровень, а также сделан вывод о необходимости интеграции введенной региональными соглашениями концепции комплексного прибрежного управления на уровень национального законодательства.
\end{abstract}

Ключевые слова: международное право, Каспийское море, охрана окружающей среды, национальное законодательство, правовая система, ответственность за ущерб, разливы нефти, стоки с рек, бассейновый принцип управления, устойчивое развитие.

Научная специальность: 12.00 .00 - юридические науки. 


\section{Введение}

Национальное законодательство играет значительную роль в вопросе реального применения норм международного (регионального) права к фактическим отношениям, и потому воздействие национального права на вопросы правовой охраны Каспийского моря остается и будет оставаться значительным. Согласно п. 2 ст. 15 Конвенции о правовом статусе Каспийского моря государства-участники вправе самостоятельно осуществлять необходимые действия для «сохранения биоразнообразия, а также защиты, восстановления, устойчивого и рационального использования биоресурсов Каспийского моря» и для «предотвращения, снижения и обеспечения контроля за загрязнением моря из любого источника».

Важно понимать, что на сложность решения экологических проблем влияет, во-первых, уникальность Каспийского моря как водоема, не имеющего соединения с Мировым океаном, во-вторых, единство экосистемы Каспия, которое определяется активным горизонтальным и вертикальным обменом вод, миграцией рыбы и тюленей, происходящими как в акватории, так и в устьях рек.

Как следствие, загрязнение одной части Каспийского моря неизбежно приводит к загрязнению другой, а также обусловливает сильную зависимость от «питающих его рек, атмосферных осадков и испарения». В реки, питающие Каспийское море, также сбрасывают промышленные отходы, которые содержат такие загрязняющие вещества, как бензин, сульфаты, фенолы, синтетические поверхностно-активные вещества и тяжелые металлы; сельскохозяйственные отходы, содержащие значительное количество органических веществ.

Загрязнение представляет особую угрозу как для морской среды и биоресурсов, так и для населения Каспийского региона. Например, в Казахстане случаи заболеваний крови и туберкулезом в четыре раза чаще встречаются у жителей Каспийского региона по сравнению с жителями осталь- ной территории государства. Загрязненная вода Каспийского моря до сих пор иногда используется в качестве питьевой воды, что является причиной целого ряда желудочнокишечных заболеваний. Наряду с этим процент заболеваемости раком у жителей Каспийского региона также является повышенным (Interim Secretariat of the Framework Convention for the Protection..., 2011).

Здесь необходимо оговориться, что в международном праве существует терминологическая проблема неопределенности соотношения терминов «охрана» и «защита». Если защита окружающей среды направлена на предотвращение угроз и противоправных деяний эколого-правового характера, она мера реагирования на возникшее нарушение охранного режима, то охрана окружающей среды включает в себя превентивные, профилактические меры. Иными словами, охрана - это не реакция на действия субъектов, а, наоборот, профилактика пресечения экологических правонарушений. Таким образом, понятие «охрана» не совпадает по содержанию с понятием «защита», однако оба термина являются составляющими единого режима сохранения окружающей среды от негативного воздействия, различие состоит лишь в этапе принятия мер, направленных на обеспечение экологической безопасности. (Экологическая безопасность является состоянием защищенности от негативного воздействия, а также включает в себя возможное последующее преследование субъектов правонарушений.) Считаем, что необходимо разграничивать термины «защита» и «охрана окружающей среды», и в настоящей статье рассматриваем именно вопросы охраны окружающей среды Каспийского моря.

На данный момент исследования по вопросу правового режима охраны окружающей среды Каспийского моря на международном уровне (среди последних можно отметить диссертационные исследования таких авторов, как Д.Г. Икаев и Н.М. Хурчак (Ikaev, 2006; Khurchak, 2006) освещают статус региона по состоянию до принятия Конвенции о правовом статусе Каспийско- 
го моря 2018 года. Дополнительную актуальность и новизну настоящей работы обуславливает ограниченность, вторичность освещения вопроса соотношения национального и международного права в рамках охраны окружающей среды Каспийского бассейна (например, Anianova, 2010; Saparov, 2016).

Соотношение международно-правовых норм об охране окружающей среды Каспийского моря и национального законодательства России, перспективы дополнения внутригосударственными нормами международно-правового режима является актуальным объектом исследования, позволяющим установить пробелы, наиболее удачные подходы и специфику, которую необходимо учитывать при формировании единых подходов к сфере охраны окружающей среды Каспийского моря на уровне всех пяти государств данного региона (Konvencija o pravovom statuse..., 2008).

\section{Соотношение норм международного права и норм национального законодательства Российской Федерации в контексте охраны окружающей среды Каспийского моря}

Соотношение международного и внутригосударственного права является одним из ключевых вопросов в теории международного права. Несмотря на существование различных теоретических подходов к данной проблеме (в первую очередь, дуалистической и двух монистических), необходимо отметить, что даже основатели дуалистического направления (Г. Трипель, Д. Анцилотти) признавали в своих работах взаимосвязь международного и национального права, выражающуюся в форме рецепции, отсылки одного права к другому, запрещения определенного вида норм, применения международного права на национальном уровне и т. д. При этом современные теоретики международного права признают высокий уровень взаимовлияния международного и национального права, выражающийся, в частности, в форме регулирования на уровне международного права межгосударственных отношений, складывающихся по поводу регулирования определенных внутригосударственных отношений или международных отношений негосударственного характера (Vylegzhanin, Andreeva, Speranskaya, 2002).

Как закреплено в п. 4 ст. 15 Конституции Российской Федерации (Konstitucija Rossijskoj Federacii, 1993), международные договоры, ратифицированные Российской Федерацией, являются частью ее правовой системы, и потому указанные акты выполняют значимую роль в деле имплементации норм международно-правовых соглашений в национальное законодательство, обеспечивая логически обусловленную юридическую связь статей отдельных внутренних нормативно-правовых актов и норм международного права. В марте 2020 года Совет Федерации Федерального собрания Российской Федерации одобрил, а Президент России В.В. Путин подписал Закон Российской Федерации о поправке к Конституции Российской Федерации от 14 марта 2020 г. № 1-ФКЗ «О совершенствовании регулирования отдельных вопросов организации и функционирования публичной власти». Согласно данному Закону ст. 79 Конституции Российской Федерации дополняется следующим положением: «Решения, принимаемые межгосударственными органами на основании положений международных договоров Российской Федерации в их истолковании, которое противоречит Конституции Российской Федерации, не подлежат исполнению на территории Российской Федерации».

Кроме того, ст. 58 Конституции гласит, что «каждый гражданин обязан защищать природу и окружающую среду, а также бережно относиться к природным богатствам». Это обязательство распространяется и на компании. К иным положениям Конституции РФ, обеспечивающим надлежащую трансформацию международноправовых норм в вопросе охраны окружающей среды Каспийского региона, можно, в частности, отнести запрет нанесения вреда окружающей среде при осуществлении своей деятельности, содержащийся в ст. 36 Конституции РФ, а также право каждого 
на благоприятную окружающую среду, достоверную информацию о ее состоянии и на возмещение ущерба, причиненного здоровью или имуществу экологическим правонарушением, закрепленное в ст. 42 Конституции РФ. Статья 72 Конституции РФ относит вопросы охраны окружающей среды, обеспечения экологической безопасности и собственно законотворчества в сфере охраны окружающей среды к сфере совместного ведения Федерации и ее субъектов, что будет более подробно исследовано ниже. Конституция практически любого государства составляет собой основу его правовой системы, и Российская Федерация не является исключением (Maximov, 2015: 27). Потому роль конституционных положений в любой сфере правового регулирования имеет определяющий характер и не может быть не упомянута в том числе в вопросе об охране окружающей среды Каспийского региона.

За последние десятилетия было принято около 30 федеральных законов, касающихся различных экологических проблем. Учитывая особый статус исследуемого Каспийского региона, установленный Конвенцией о правовом статусе Каспийского моря 2018 года, к нормативно-правовым актам федерального уровня, в которых закреплены нормы, применимые к охране окружающей среды Каспийского моря, можно отнести: Федеральный закон (ФЗ) «Об охране окружающей среды» 2002 года, Ф3 «О внутренних морских водах, территориальном море и прилежащей зоне Российской Федерации» 1998 года, Ф3 «Об экологической экспертизе» 1995 года, Ф3 «О недрах» 1992 года, Ф3 «О соглашениях о разделе продукции» 1995 года, Водный кодекс Российской Федерации 2006 года.

\section{Соотношение Федерального закона «Об охране окружающей среды» и региональных соглашений}

Ранее были перечислены основные направления регулирования, которые Тегеранская конвенция предлагает отразить в соответствующих Протоколах и актах национального права. Представляется, что положения Федерального закона «Об охране окружающей среды» выполняют эту функцию (Zhochkina, 2015: 7). Так, в соответствии с разделом III Конвенции, посвященным предотвращению, снижению и контролю за загрязнением вод Каспийского моря, в ст. 16 Закона устанавливается необходимость взимания платы за негативное воздействие на окружающую среду, в том числе за сброс загрязняющих веществ, осуществляемый в водные объекты (Federal'nyj zakon.., 2002). Содержащийся в Конвенции принцип использования наилучших существующих технологий находит свое отражение в одноименной статье 28.1 Закона. Необходимость применения таких технологий для очистки городских сточных вод, для сокращения притока органических веществ, перемещаемого из коммунальных и промышленных источников, также содержащаяся в ст. 7 Конвенции, реализуется в перечне областей применения наилучших доступных технологий, установленном Правительством Российской Федерации. Норма о необходимости лицензирования сбросов сточных вод из раздела III Тегеранской конвенции тоже находит свое отражение в Законе. Так, бланкетная норма ст. 30 Закона «Об охране окружающей среды», посвященная лицензированию отдельных видов деятельности в сфере охраны окружающей среды, отсылает нас к положениям Федерального закона «О лицензировании отдельных видов деятельности» 2011 года, ст. 12 которого содержит соответствующие нормы.

Положения раздела IV Конвенции, посвященной оценке воздействия на окружающую среду в трансграничном контексте 1991 года, реализуются на национальном уровне посредством ст. 32 Закона «Об охране окружающей среды», которая, в свою очередь, отсылает нас к ряду подзаконных актов, основным из которых выступает Приказ Госкомэкологии Российской Федерации «Об утверждении Положения об оценке воздействия намечаемой хозяйственной и иной деятельности на окружающую среду в Российской Федерации». Положениям о необходимости осуществления экологического 
мониторинга из раздела IV Рамочной конвенции соответствует глава X Закона, посвященная государственному мониторингу в сфере экологии или государственному мониторингу окружающей среды. Так, Законом создается Единая система государственного экологического мониторинга, одними из направлений деятельности которой выступают государственный мониторинг водных объектов и государственный мониторинг водных биоресурсов. Им соответствуют Постановление Правительства Российской Федерации «Об утверждении Положения об осуществлении государственного мониторинга водных объектов» 2007 года и Постановление Правительства Российской Федерации «Об утверждении Положения об осуществлении государственного мониторинга водных биологических ресурсов и применении его данных» 2008 года.

В Законе «Об охране окружающей среды» изложены основополагающие принципы российского экологического права, и ожидается, что государственные органы будут применять их при соблюдении природоохранного законодательства. Закон об охране окружающей среды обеспечивает основу для экологического регулирования в Российской Федерации в целом. Он включает такие принципы, как принцип потенциальной экологической опасности, полной компенсации за ущерб, нанесенный окружающей среде, принцип оценки воздействия на окружающую среду. В отдельной главе Закон об охране окружающей среды устанавливает общие требования к различным видам экономической деятельности, включая выбор места расположения, строительства и эксплуатации различных типов объектов, регулирует вопросы, связанные с ввозом радиоактивных отходов. Он определяет общие черты правового режима в отношении особо охраняемых территорий.

Приведенные примеры не исчерпывают широкую сферу пересечения и совпадения положений Федерального закона «Об охране окружающей среды» и Рамочной конвенции. Представляется, что ключевым обстоятельством при этом выступает совпадение целей и принципов обоих нормативных актов. Так, сформулированные в Конвенции основные отраслевые принципы - принятие мер предосторожности, «загрязняющий платит», и доступность информации о загрязнении - находят свою имплементацию в ст. 3 Закона, где помимо них отмечаются следующие принципы: принцип соблюдения права человека на благоприятную окружающую среду, принцип обеспечения благоприятных условий жизнедеятельности человека, принцип приоритета сохранения естественных экологических систем, природных ландшафтов и природных комплексов, принцип сохранения биологического разнообразия, ответственности за нарушение законодательства в области охраны окружающей среды, принцип участия граждан, общественных объединений и некоммерческих организаций в решении задач охраны окружающей среды, а также ряд других принципов, включая принцип необходимости участия в деятельности по международному сотрудничеству в целях обеспечения охраны окружающей среды, который распространяется как на межгосударственное сотрудничество, так и на сотрудничество с международными организациями и иными образованиями, имеющими международную правосубъектность. Представляется, что формулировка ст. 5 Конвенции не исключает, а, напротив, поощряет включение всех перечисленных принципов в предмет своего регулирования, что способно лишь повысить степень эффективности защиты окружающей среды Каспийского региона.

\section{Федеральный закон «О внутренних морских водах, территориальном море и прилежащей зоне Российской Федерации» в контексте Конвенции о правовом режиме Каспийского моря 2018 года}

Определение о правовом статусе Каспийского моря ставит вопрос о возможности применения к вопросам охраны окружающей среды Каспийского региона норм Федерального закона «О внутренних морских водах, территориальном море и при- 
лежащей зоне Российской Федерации» (Federal'nyj zakon.., 1998). Ст. 13 Конвенции о правовом статусе Каспийского моря содержит положение о том, что осуществление суверенитета каждого из государств, подписавших договор, реализуется в том числе в форме исключительного права на регулирование, проведение и разрешение в своих территориальных водах морских научных исследований. Не углубляясь в теорию вопроса о терминологическом различии формулировки «территориальные воды», присущей Конвенции, и «территориальное море», присущей Закону, отметим, что положения о проведении морских научных исследований и исследований морских ресурсов, содержащиеся в главе IV Закона, могут быть распространены и на российскую часть акватории (дна) Каспийского моря, поскольку иных положений в отношении соответствующих исследований российское законодательство не содержит. При этом ст. 20 Тегеранской конвенции предусматривает необходимость проведения научных исследований, а также «разработки эффективных методов предотвращения, снижения и контроля загрязнения морской среды Каспийского моря». В Законе же содержится четко регламентированный порядок осуществления соответствующих исследований, предусматривающий участие юридических иностранных лиц и порядок опубликования результатов исследования, которые могут быть предоставлены и иным субъектам, помимо субъектов внутригосударственного права Российской Федерации. Предлагаем уточнение и закрепление данного аспекта в российском законодательстве.

Аналогичные вопросы возникают и в отношении главы V указанного Закона, посвященной защите и сохранению морской среды и природных ресурсов внутренних морских вод и территориального моря. Конвенция о правовом статусе Каспийского моря, в свою очередь, использует формулировки «внутренние воды» и «территориальные воды». Представляется, что для целей правового регулирования вопросов защиты окружающей среды Каспийского региона различие указанных терминов не является столь существенным, поскольку, во-первых, Конвенция оперирует формулировками применительно к единому водоему и, во-вторых, в вопросах эколого-правового характера стороны вправе применять самостоятельно меры защиты в пределах своей юрисдикции, как отмечается в ранее упомянутой ст. 14 Конвенции. Обращаясь к содержанию рассматриваемой главы, отметим его полное соответствие нормам Рамочной конвенции. Так, глава V включает в себя, помимо отраслевых принципов, положения о поддержании на должном уровне качества морской среды, биоразнообразия в море, предотвращения загрязнений, об осуществлении государственной экологической экспертизы, надзора и мониторинга в сфере экологии. Кроме того, глава V включает в себя положения о предотвращении и ликвидации последствий морских аварий.

Экологическая экспертиза согласно ст. 2 соответствующего Закона (Federal'nyj zakon..., 1995) представляет собой процедуру установления соответствия документации, призванную обосновывать намечаемую хозяйственную и иную деятельность экологическим требованиям в целях предотвращения последующего негативного воздействия такой деятельности на окружающую среду. Следует отметить, что нормы о проведении экологической экспертизы включены в значительное количество нормативно-правовых актов Российской Федерации и ее субъектов, что позволяет некоторым исследователям говорить о существовании системы законодательства об экологической экспертизе. Так, к их числу относятся такие подзаконные акты, как Постановление Правительства Российской Федерации «Об утверждении Положения о порядке проведения государственной экологической экспертизы» 1996 года и Приказ Росрыболовства «Об утверждении Административного регламента Федерального агентства по рыболовству по исполнению государственной функции по разработке и представлению на государственную экологическую экспертизу» 2010 года. Исследователями отмечается особая значимость 
института экологической экспертизы в деле защиты окружающей среды, поскольку процесс ее осуществления предусматривает, помимо действий органов государственной власти, участие населения и общественных организаций (Khaustov, 2012: 47), что делает ее комплексным и эффективным правовым инструментом. Говоря о соответствии положений указанных актов нормам международного права, следует отметить, что необходимость формирования и законодательного закрепления механизмов по обеспечению экологической безопасности на Каспийском море, включая вопросы оценки негативного воздействия на окружающую среду, экологического контроля и экспертизы закреплена в преамбуле Соглашения между Российской Федерацией и Республикой Казахстан о разграничении дна северной части Каспийского моря, что также соответствует целям и принципам Тегеранской конвенции.

\section{Правовое регулирование охраны окружающей среды Каспийского моря от основных видов загрязнений (разливы нефти, загрязнение стоков рек)}

Добыча и транспортировка углеводородного сырья - основные источники загрязнения морской среды и воздуха в Каспийском регионе, как следствие, затопления скважин, разливов и утечек сырья. В процессе разработки месторождений углеводородов ежегодно в воду попадает около 1 млн т нефти. Согласно данным трансграничного мониторинга Каспийского моря 2012-2014 годов, основным источником нефтяных разливов являются сбросы нефтепродуктов с судов.

Дополнительными факторами, способствующим загрязнению углеводородами, выступают природные источники поступления углеводородов, что свойственно средней и особенно южной частям Каспийского моря. Загрязнение происходит при выходе на поверхность подземных флюидов (смесей нефти, воды и газа) и нефтегазовых углеводородов на дне моря в процессе активности грязевых вулканов и внезапных прорывов на поверхность флюидов вследствие нарушения гидродинамического равновесия. Данный фактор загрязнения есть обстоятельство, осложняющее проведение региональной оценки степени загрязнения углеводородами морской среды Каспийского моря.

Статья 29 Тегеранской конвенции устанавливает, что государства-участники должны дополнительно разработать правила и процедуры, закрепляющие материальную ответственность и компенсацию за нанесенный ущерб. Данный вопрос еще не был урегулирован, при этом одним из основных и наиболее опасных видов загрязнений, возможных в Каспийском море, являются разливы нефти (Janusz-Pawletta, 2015). В этой связи необходимо рассмотреть, какие правовые механизмы, существующие на национальном уровне в Российской Федерации, могли бы лечь в основу дальнейших дополнений региональных международноправовых механизмов по установлению ответственности за загрязнение Каспийского моря от разливов нефти.

Протокол о региональной готовности, реагировании и сотрудничестве в случае инцидентов, вызывающих загрязнение нефтью («Актауский протокол»), был принят и подписан на третьем совещании Конференции сторон (КС-3) в г. Актау, Казахстан, 12 августа 2011 года. Вышеупомянутый протокол является первым ратифицированным всеми сторонами Азербайджаном, Ираном, Казахстаном, Российской Федерации и Туркменистаном - протоколом к Тегеранской конвенции и вступил в силу 25 июля 2016 года.

Положения данного протокола акцентируются на нефтяных загрязнениях как на одной из главных угроз водному объекту; стороны соглашаются, что необходимо вынесение положений о создании специальных мер при возникновении подобных инцидентов. Важность уровня подготовки государства к борьбе с загрязнениями на национальном уровне, осуществления взаимопомощи и международного сотрудничества между сторонами-участницами отражена в протоколе. Подчеркнута так- 
же важность мер, которые принимаются как индивидуально отдельными странами, так и совместно для минимизации рисков инцидентов, связанных с загрязнением нефтью в Каспийском море (Zhochkina, 2015: 9). Стороны протокола выражают намерение договаривающихся сторон защитить морскую среду Каспийского моря и прибрежные районы от загрязнения нефтью, принимая во внимание имеющиеся соответствующие международные конвенции и, в частности, те, которые затрагивают положения об уровне подготовки и реагировании на случаи загрязнения нефтью, а также ответственность и компенсацию за ущерб от загрязнения (Protokol o regional'noj gotovnosti..., 2011).

В соответствии с положениями, установленными Протоколом, участвующие стороны принимают по отдельности или совместно все меры, необходимые для осуществления Протокола, для подготовки к случаям, связанным с загрязнением нефтью, и реагирования на них. Стороны совместно разрабатывают и устанавливают руководящие принципы для соответствующих практических, эксплуатационных и технических аспектов совместных действий, создают специальный региональный механизм, процедуры которого должны быть рассмотрены и впоследствии приняты Конференцией сторон. Устанавливается, что в целях оперативного осуществления Протокола сторонами будет установлен Каспийский план регионального сотрудничества в борьбе с загрязнением нефтью в чрезвычайных ситуациях.

Статья 5 Протокола посвящена национальным системам и планам действий в чрезвычайных ситуациях для борьбы с инцидентами загрязнения нефтью. Каждая из договаривающихся сторон создает национальную систему оперативного реагирования на загрязнение нефтью. Эта система должна включать следующие параметры: a) назначение Компетентного национального органа, ответственного за готовность и реагирование на инциденты загрязнения нефтью; б) национальный оперативный контактный пункт, отвечающий за получе- ние и передачу информации о случаях загрязнения нефтью, как указано в п. 4 ст. 7 настоящего Протокола; в) компетентный национальный орган имеет право действовать от имени договаривающейся стороны, чтобы запросить помощь или принять решение об оказании запрашиваемой помощи. Каждая договаривающаяся сторона должна составить и реализовать национальный план действий в чрезвычайных ситуациях для обеспечения готовности и реагирования на инциденты, связанные с загрязнением нефтью. Государственный национальный план действий в чрезвычайных ситуациях должен включать в себя следующие пункты: а) положения, описывающие административную организацию и ответственность, налагаемую на каждый из составляющих органов при подготовке и борьбе с инцидентами, вызванными загрязнением нефтью; б) определение возможных источников выбросов нефти; в) описание оборудования и человеческих ресурсов, которые могут быть использованы для борьбы с инцидентами загрязнения нефтью; г) спецификация мер временного хранения и окончательной утилизации собранной нефти.

В случае возникновения необходимости каждая сторона-участница устанавливает минимальный уровень предварительно установленного оборудования, чтобы иметь возможность эффективно работать со сбросами нефти, осуществляя эту деятельность в сотрудничестве с предприятиями нефтяной и судоходной промышленности, администрациями порта и любыми другими соответствующими организациями, и поддерживает в рабочем состоянии. Количество оборудования должно соответствовать тому количеству оборудования, которое может понадобиться при определенном риске загрязнения нефтью. Каждая из договаривающихся сторон самостоятельно или в рамках двустороннего или многостороннего сотрудничества устанавливает программы по проведению учений и подготовке персонала для улучшения состояния готовности органов, ответственных за решение вопросов, связанных с загрязнением нефтью. 
В Протоколе предусмотрены положения об обмене между сторонами информацией и еe распространении, согласно которым каждая из сторон составляет и передает в секретариат доклад о степени осуществления Протокола, а также обязуется либо напрямую, либо через региональный механизм распространять среди других сторон следующую информацию: а) информацию, предписанную в п. 1 статьи 5 и 2 (а) настоящего Протокола; б) информацию об использовании новых способов предотвращения загрязнения морской среды нефтью и о новых эффективных мерах, применяемых в борьбе с загрязнением, включая результаты исследовательских программ; в) информацию о крупных инцидентах, связанных с загрязнением нефтью.

Протокол также регламентирует порядок уведомления сторонами друг друга о загрязнении, оперативные меры в случаях разливов нефти, планы действий на борту судов, на морских установках, в морских портах и на объектах по переработке нефти в чрезвычайных ситуациях, связанных с загрязнением нефтью. Отдельно вынесены положения о взаимопомощи сторон в случаях с инцидентами загрязнения и возмещении расходов, вызванных оказанием этой помощи.

Во второй главе Протокола рассматриваются организационные положения об организационных структурах, а также функции регионального механизма, который оказывает содействие в оперативном и эффективном реагировании на случаи загрязнения договаривающимся сторонам.

К национальным нормам российского законодательства относятся положения Федерального закона № 287-Ф3 «О внесении изменений в Федеральный закон «О континентальном шельфе Российской Федерации» и Федеральный закон «О внутренних морских водах, территориальном море и прилежащей зоне Российской Федерации» от 30 декабря 2012 года. Данный Закон устанавливает обязанность эксплуатирующей организации по организации и проведению мероприятий, направленных на предотвращение загрязнения моря нефтью при осуществлении промышленной деятельности на континентальном шельфе. При осуществлении мероприятий, направленных на предупреждение разливов нефти и нефтепродуктов, эксплуатирующая организация должна создать систему наблюдений за состоянием морской среды в районе, где она осуществляет свою деятельность (в том числе систему обнаружения разливов нефти и нефтепродуктов), систему связи и оповещения о возникших разливах нефти и нефтепродуктов, соответствующие требованиям, которые установлены Правительством Российской Федерации, и обеспечить функционирование таких систем; иметь финансирование для осуществления мероприятий, предусмотренных планом предупреждения и ликвидации разливов нефти и нефтепродуктов, включая возмещение в полном объеме ущерба, причиненного окружающей среде, в том числе водным биоресурсам, жизни, здоровью и имуществу граждан, имуществу юридических лиц в результате разливов нефти и нефтепродуктов.

В соответствии с положениями Постановления Правительства Российской Федерации № 613 (в ред. Постановления Правительства РФ от 15.04.2002 № 240) от 21 августа 2000 года в зависимости от таких показателей, как объем и площадь разлива нефти и нефтепродуктов на территории, во внутренних пресноводных водоемах выделяются чрезвычайные ситуации пяти видов (локального, муниципального, территориального, регионального, федерального значения) - чрезвычайные ситуации подразделяются на виды исходя из их объема и территории разлива. В зависимости от объема разлива нефти и нефтепродуктов на морском пространстве выделяются три вида чрезвычайных ситуаций (локального, регионального и федерального значения) в зависимости от объема разлива нефти или нефтепродуктов.

Согласно положениям Постановления Правительства РФ «Об утверждении Положения об осуществлении государственного мониторинга водных объектов» от 10 апреля 2007 года № 219 устанавливается госу- 
дарственный мониторинг, цель которого своевременное выявление и прогнозирование негативного воздействия, оказываемого на водные объекты, а также развития негативных процессов, которые оказывают влияние на состояние водных объектов и качество воды в них; разработка и проведение комплексов мероприятий по предотвращению негативных последствий, вызванных этими процессами.

Эта категория наблюдений состоит из мониторинга поверхностных водных объектов с учетом данных мониторинга, осуществляемого во время проведения работ в сфере гидрометеорологии и смежных с ней сферах; мониторинга состояния дна и берегов водных объектов, а также состояния водоохранных зон; мониторинга подземных вод с учетом данных государственного мониторинга состояния недр; наблюдений за водохозяйственными системами, в том числе за гидротехническими сооружениями, за объемом вод при водопотреблении и сбросе вод, в том числе сточных, в водные объекты.

В числе ключевых подзаконных актов, служащих делу защиты окружающей среды Каспийского региона, помимо вышеназванных, следует указать План комплексного стимулирования освоения месторождений углеводородного сырья на континентальном шельфе Российской Федерации и в российской части (российском сектоpe) дна Каспийского моря (Rasporjazhenie Pravitel'stva.., 2014), Приказ «Об утверждении Административного регламента Федеральной службы безопасности Российской Федерации по исполнению государственной функции по осуществлению государственного контроля в сфере охраны морских биологических ресурсов», изданный Федеральной Службой Безопасности России (Prikaz FSB Rossii.., 2012) и другие акты.

Закон «О соглашениях о разделе продукции» затрагивает Каспийскую акваторию постольку, поскольку в отношениях России и Казахстана достаточно долгое время рассматривается вопрос о совместной разработке Хвалынского месторождения обеими сторонами. Закон предусматри- вает обязанность принятия необходимых мер по защите окружающей среды при осуществлении соответствующих работ, обязательного страхования ответственности по возмещению ущерба в случае аварий, которые повлекли за собой вредное влияние на окружающую среду, ликвидации последствий такого воздействия (Federal'nyj zakon.., 1995). Принятие Правительством РФ дополнительных мер, направленных на защиту окружающей среды, согласно положениям ст. 17 Закона является одним из исключений из действия стабилизационной оговорки для инвестора. Представляется, что вопросы защиты окружающей среды региона будут реализованы в разрабатываемом соглашении на основании положений указанного Закона, и потому нельзя исключать сферу его действия из рассматриваемой нами межгосударственной и комплексной системы охраны окружающей среды Каспийского моря.

Помимо указанных актов, реализации положений международно-правовых актов способствуют также акты налогового законодательства РФ. Отдельно следует отметить экологическую функцию налоговых платежей. Так, Каспийскому морю как объекту был присвоен специальный коэффициент экологической значимости, который используется при расчете суммы платы за причиненное негативное воздействие. Представляется, что налоговое законодательство может выступать достаточно эффективным инструментом охраны окружающей среды, в том числе Каспийского региона, поскольку высокие ставки соответствующих платежей обеспечивают несомненную экономическую заинтересованность субъекта хозяйственной и иной экономической деятельности в необходимости обеспечения состояния экологической обстановки региона на должном уровне. Налоговый кодекс РФ выполняет и иную функцию. Например, в ст. 147, как и в ряде иных статей, содержится следующая формулировка: «товар находится на континентальном шельфе Российской Федерации и (или) в исключительной экономической зоне Российской Федерации либо в рос- 
сийской части (российском секторе) дна Каспийского моря». Таким образом, законодатель недвусмысленно подчеркивает особый статус Каспийской акватории, отличный от правоотношений, складывающихся в исключительной экономической зоне Российской Федерации и на континентальном шельфе.

В Конвенции о правовом статусе Каспийского моря, принятой в 2018 году, Каспийское море получило юридический статус озера. В то же время для целей охраны окружающей среды Каспийское море должно рассматриваться как бассейн. Принцип бассейнового управления ресурсами Каспийского моря уже получил свое закрепление в ряде предыдущих соглашений каспийских государств (например, в Соглашении, заключенном между Правительством Российской Федерации и Правительством Исламской Республики Иран о сотрудничестве в области рыбного хозяйства от 18 мая 1996 года), а также отражен в документах Программы развития ООН. Принцип бассейнового управления ресурсами подразумевает, что право охраны окружающей среды должно устанавливать ответственность за ущерб от различных источников загрязнения даже в том случае, когда они физически связаны с иными природными объектами (атмосфера над Каспийским морем, сток впадающих рек, грунтовые воды и проч.). Среди таких источников загрязнения сток с рек, включая промышленный сток, является наиболее опасным, а вопрос установления ответственности за него - наиболее актуальным. Статья 20(е) Тегеранской конвенции отдельно указывает на необходимость дальнейшей разработки безопасных методов регулирования речного стока, а п. (f) той же статьи предусмотрено объединение усилий государств по выработке единых методов оценки ущерба, причиненного загрязнением.

В декабре 2012 года к Рамочной конвенции 2003 года был принят Протокол по защите Каспийского моря от загрязнения из наземных источников и в результате осуществляемых на суше видов деятельности на четвертой сессии Конференции Сторон
(КС4) в г. Москве, именуемый «Московский протокол». Фактически принятие сторонами данного Протокола стало закреплением интегрирования принципа бассейнового управления морскими ресурсами на уровне региональных международных соглашений Каспийского региона.

В статьях 4-6 Протокола утверждены меры его выполнению, описаны принципы, которыми руководствуются участники, в том числе известный принцип «загрязнитель платит», а также используемые соответствующими компетентными органами нормы и критерии, в том числе для разработки региональных программ и планов действий (Protokol po zashhite Kaspijskogo morja.., 2012).

Помимо основных положений, в протокол вынесены положения об информации и сборе данных, мониторинге и оценке. В рамках положений и программ мониторинга, предусмотренных в ст. 19 Тегеранской конвенции, и при необходимости в сотрудничестве с компетентными международными организациями договаривающиеся стороны по мере возможности должны осуществлять: а) сбор данных и информации, подготовку и ведение национальной базы данных о состоянии морской среды и прибрежных районов Каспийского моря с точки зрения его физических, биологических и химических характеристик; б) сбор данных и информации, подготовку и ведение национальной базы данных, содержащей сведения о поступающих из наземных источников веществах, перечисленных в Приложении к Протоколу, включая информацию о распределении источников и количествах таких веществ, поступивших в морскую среду и прибрежные районы Каспийского моря; в) регулярно проводить региональную оценку (не реже чем один раз в пять лет) состояния морской среды и районов Каспийского моря; г) систематически оценивать уровни загрязнения вдоль своих береговых линий, в частности, в отношении видов деятельности и веществ, которые перечислены в Приложении к Протоколу, и регулярно предоставлять информацию по этому вопросу секретариату. Договари- 
вающиеся стороны осуществляют сотрудничество по созданию элементов региональной программы мониторинга, а также совместимых национальных программ мониторинга с аналитическим контролем качества для содействия хранению, поиску и обмену данными.

Протокол устанавливает также систему отчетности сторон о предпринятых мерах по его выполнению.

Реки, озера, моря и другие водные объекты зачастую могут пересекать границы государства и находиться на территории двух и более смежных государств. Применение описанного принципа бассейнового управления, вовлечение в его использование других участников дают возможность полноценно исследовать природные характеристики водных объектов и эффективно управлять ими, вместе с тем способствуя улучшению координирования действий между разными государствами и их ключевыми в этой сфере органами.

В национальном законодательстве прикаспийских государств данный принцип находит свое отражение как один из основных. Так, в ст. 16 Водного кодекса Азербайджана от 26 декабря 1996 года принцип бассейнового управления указывается как один из ключевых в сфере использования и охраны водных ресурсов. В Водном кодексе Республики Казахстан от 9 июля 2003 года включено требование о внедрении описанного принципа в стране. Статья 34 Кодекса называет принцип бассейнового управления одним из основных в сфере управления водными ресурсами, более того, ст. 43 Кодекса устанавливает создание так называемых бассейновых советов, выступающих совещательными органами по соответствующему бассейну. Рассмотрим правовые нормы национального законодательства Российской Федерации на предмет внедрения принципа бассейнового управления природными ресурсами, применимого к Каспийскому морю.

Статья 5 Водного кодекса Российской Федерации от 03.06.2006 № 74-ФЗ включает «моря или их отдельные части», а также «водоемы (такие, как озера, пруды, обводненные карьеры, водохранилища)» в состав поверхностных водных объектов, что позволяет судить о применимости соответствующих норм к исследуемой сфере. Охране окружающей среды водных объектов посвящены отдельные положения главы 6 Кодекса. Так, в частности, ст. 56 запрещает: осуществлять сброс в водные объекты и захоронение в водных объектах отходов производства и потребления, в том числе судов, выведенных из эксплуатации, иных плавучих средств (их частей и механизмов); захоронение в водных объектах ядерных материалов, радиоактивных веществ; сброс в водные объекты сточных вод, содержание в которых радиоактивных веществ, пестицидов, агрохимикатов и других опасных для здоровья человека веществ и соединений превышает нормативы допустимого воздействия на водные объекты и др. Во избежание повторения вышеизложенных положений отметим лишь, что Кодекс устанавливает специальные водоохранные зоны и прибрежные защитные полосы в целях защиты природной среды водных объектов, а также содержит отсылки к вышеназванным актам, в частности, по вопросам предотвращения экологических катастроф. Представляется, что несмотря на то, что вопросы защиты окружающей среды не являются целевым назначением Кодекса, его положения безусловно необходимы для создания предписанной Рамочной конвенцией комплексной системы охраны окружающей среды Каспийского региона.

Вопрос о применимости Федерального закона «О недрах» к рассматриваемым автором правоотношениям аналогичен рассмотренному ранее вопросу Федерального закона «О внутренних морских водах, территориальном море и прилежащей зоне Российской Федерации». Считаем, что, основываясь на ранее высказанных предположениях, формулировка об отнесении к числу участков недр федерального значения участков недр «внутренних морских вод, территориального моря, континентального шельфа Российской Федерации», которая закреплена в ст. 2.1 Закона, обуславливает 
включение данного акта в комплекс законодательных актов, обеспечивающих защиту окружающей среды Каспийского региона. Так, ст. 23 предусматривает необходимость «предотвращения размещения отходов производства и потребления на водосборных площадях подземных водных объектов и в местах залегания подземных вод, которые используются для целей питьевого водоснабжения или технологического обеспечения водой объектов промышленности либо объектов сельскохозяйственного назначения или резервирование которых осуществлено в качестве источников питьевого водоснабжения».

Согласно положениям Постановления Правительства Российской Федерации «Об утверждении Положения об осуществлении государственного мониторинга водных биологических ресурсов и применении его данных» от 24 декабря 2008 г. N994 мониторинг представляет собой осуществляемую с помощью технических средств (космические, информационные технологии) систему наблюдений, позволяющую отслеживать качество, численность, распределение и воспроизводство биологических ресурсов, выступающих в качестве объекта рыболовства или же в качестве среды обитания. Кроме того, мониторинг в соответствии с рассматриваемой нормой включает наблюдение за рыболовством и сохранением биоресурсов водной среды.

Законодательство об уголовнои административно-правовых нарушениях также составляет важную часть системы правовой охраны окружающей среды, поскольку зачастую привносит в рассмотренные выше нормы необходимый элемент применения к нарушителю мер административно-правового и уголовного характера (Suleymanova, 2016: 108). Так, глава 8 Кодекса Российской Федерации об административных правонарушениях (Kodeks Rossijskoj Federacii.., 2001) посвящена административным правонарушениям в области охраны окружающей среды и природопользования. Следует выделить: нарушение норм законодательства об экологической экспертизе (ст. 8.4 КоАП РФ), сокрытие или искажение экологической информации (ст. 8.5 КоАП РФ), нарушение требований по охране недр и гидроминеральных ресурсов (ст. 8.9 КоАП РФ), нарушение правил охраны водных объектов (ст. 8.13 КоАП РФ), нарушение правил водопользования (ст. 8.14 КоАП РФ), нарушение правил эксплуатации водохозяйственных или водоохранных сооружений и устройств (ст. 8.15 КоАП РФ) и др.

Следует отметить, что нормы российского законодательства об административных правонарушениях обеспечивают реализацию большинства направлений, указанных в разделах III и IV Рамочной конвенции, что позволяет считать их важной частью комплексной системы охраны окружающей среды Каспийского региона. Так, в судебной практике российских судов встречаются дела о привлечении к ответственности за несанкционированный сброс сточных (коммунальных) отходов без соответствующей очистки на рельеф местности в водоохранной зоне Каспийского моря по ст. 8.41 КоАП (Postanovleniem Arbitrazhnogo suda.., 2016); за нарушение законодательства о недрах, способное повлечь загрязнение подземных вод и Каспийского моря (Postanovlenie FAS.., 2017) и др. Постановление Пятнадцатого арбитражного апелляционного суда от 01.12.2009 № 15АП-8114/2009 по делу № А53-12787/2009 об оставлении решения суда без изменений. Постановлением Арбитражного суда Ростовской области от 29.07.2009 по делу № А53-12787/2009 было оставлено в силе постановление Департамента Федеральной службы по надзору в сфере природопользования по Южному федеральному округу по делу об административном правонарушении Федерального государственного унитарного предприятия «Росморпорт». Предприятие, не имея на то разрешения компетентного органа государственной власти, осуществило сброс донных отложений со своих судов через рефулеры в Каспийское море. Являясь водопользователем, именно общество должно нести административную ответственность за нарушение правил проведения дноуглу- 
бительных работ на водном объекте, предоставленном ему в пользование.

Экологическим преступлениям посвящена глава 26 Уголовного кодекса РФ (Ugolovnyj kodeks Rossijskoj Federacii.., 1996). К числу интересующих нас составов относятся следующие: загрязнение вод (ст. 250 УК РФ), предположительно загрязнение морской среды (ст. 252 УК РФ), незаконная добыча (вылов) водных биологических ресурсов (ст. 256 УК РФ), нарушение правил охраны водных биологических ресурсов (ст. 257 УК РФ), незаконные добыча и оборот особо ценных диких животных и водных биологических ресурсов, принадлежащих к видам, занесенным в Красную книгу РФ и (или) охраняемым международными договорами Российской Федерации (ст. 258.1 УК РФ) и др. В числе мер уголовноправовой ответственности за данные правонарушения предусматриваются: штраф, лишение права занимать определенные должности или заниматься определенной деятельностью, обязательные работы, исправительные работы, а также лишение свободы. Каспийское море относится некоторыми исследователями к числу регионов с достаточно криминализированной обстановкой в отношении названных экологических составов преступлений (Maximov, 2015: 26).

Анализ судебной практики, в свою очередь, демонстрирует ситуацию абсолютного приоритета привлечения к ответственности в соответствующей сфере в рамках административно-правового преследования. Тем не менее нормы уголовноправового характера следует отнести к числу значимых гарантий охраны окружающей среды Каспийского моря.

\section{Правовая характеристика}

внутринациональных органов Российской

Федерации и международных органов

в контексте охраны окружающей среды

Каспийского моря

В соответствии с п. 3 ст. 7, подпунктом g п. 10 ст. 22 Рамочной конвенции по защите морской среды Каспийского моря договаривающиеся стороны будут осуществлять сотрудничество в принятии всех соответствующих мер для предотвращения, сокращения и контроля загрязнения, включая, где это уместно, создание совместных органов, ответственных за выявление и решение потенциальных проблем загрязнения; функции Конференции сторон заключаются также в создании таких вспомогательных органов, которые могут быть сочтены необходимыми для осуществления настоящей Конвенции и протоколов к ней (Ramochnaja konvencija po zashhite.., 2003).

Согласно положениям ст. 11 Протокола по защите Каспийского моря от загрязнения из наземных источников и в результате осуществляемых на суше видов деятельности («Московский Протокол») от 12 декабря 2012 года к Тегеранской конвенции если сброс веществ из водотока, протекающего через территории двух или более договаривающихся сторон, образует границу между ними, вызывает или может вызвать загрязнение морской среды Каспийского моря, соответствующие договаривающиеся стороны затрагиваемых территорий будут осуществлять сотрудничество для того, чтобы обеспечить полное применение Протокола, в том числе в случае необходимости путем создания совместных органов, отвечающих за обнаружение и последующее решение проблем загрязнения (Protokol po zashhite Kaspijskogo morja.., 2012). Согласно положениям протокола Конференция договаривающихся сторон вправе создавать любые вспомогательные органы, которые могут быть признаны необходимыми для выполнения Протокола, в соответствии с п. 9 (a) и (c) ст. 22 Рамочной конвенции.

Подпункт f п. 1 ст. 12 Протокола о региональной готовности, реагировании и сотрудничестве в случае инцидентов, вызывающих загрязнение нефтью («Актауский протокол»), от 12 августа 2011 года устанавливает, что для целей настоящего Протокола и в соответствии с п. 10 ст. 22 Конвенции Конференция сторон, в частности, создает такие вспомогательные органы, которые могут быть сочтены необходимыми 
для осуществления настоящего Протокола (Protokol o regional'noj gotovnosti.., 2011).

В данный момент мониторинг за состоянием окружающей среды водных объектов, в частности Каспийского моря, на международном уровне осуществляет Международная морская организация (International Maritime Organization), образованная в Женеве 6 марта 1948 года с принятием Конвенции о Межправительственной морской консультативной организации, основными функциями которой являются ответственность за организацию обеспечения безопасности на море и защиты окружающей среды, облегчение взаимодействия правительств государств по техническим вопросам для достижения высочайших стандартов в области безопасности на море и предотвращения загрязнения; Программа $\mathrm{OOH}$ по окружающей среде (United Nations Environment Programme), осуществляя свою деятельность на уровне предоставления регулярных отчетов о состоянии мировых водных объектов, в частности Каспийского моря (UNEP, 2020). Однако деятельность указанных органов в отношении Каспийского моря носит в основном обозревательный характер. Ранее странами уже предпринимались попытки по созданию единой организации по работе непосредственно в Каспийском море, например, ныне не действующая Организация Сотрудничества между Прибрежными Государствами («Organisation for Co-operation between the Caspian Littoral States») 1992 года, Каспийская Экологическая Программа («Caspian Environmental Programme») 1998 года и еe локальные органы, именуемые региональными тематическими центрами для развития Национальных Каспийских Планов Действий, одним из результатов деятельности которой стало подписание всеми прикаспийским государствами Тегеранской конвенции.

На национальном уровне прикаспийские государства обладают внутренними органами, полномочия которых распространяются на защиту окружающей среды. Как было показано выше, в Российской Федерации в систему органов, осуществляю- щих экологический мониторинг и различные виды деятельности в рамках охраны окружающей среды, входят специально уполномоченные государственные органы в области охраны окружающей среды, использования и охраны отдельных видов природных ресурсов: Министерство природных ресурсов и экологии РФ (Минприроды России), которое осуществляет государственное управление в сфере природопользования, охраны окружающей среды и обеспечения экологической безопасности; Федеральная служба по надзору в сфере природопользования (Росприроднадзор), осуществляющая функции по контролю и надзору в области природопользования, в том числе в области, касающейся ограничения негативного техногенного воздействия, в области обращения с отходами (за исключением радиоактивных отходов) и государственной экологической экспертизы (Postanovlenie Pravitel'stva RF.., 2004); Федеральное агентство водных ресурсов (Росводресурсы), обеспечивающее в рамках своей компетенции проведение мероприятий по рациональному использованию, восстановлению, а также охране водных объектов, предупреждению и ликвидации вредного воздействия вод (Khurchak, 2006).

Ввиду специфики расположения Каспийского моря, его замкнутости изменения в какой-то его части так или иначе в конечном итоге сказываются на всей его экосистеме в целом, в связи с чем для сохранения уникального водоема необходимо скоординированное сотрудничество всех прикаспийских государств. Поскольку в 2018 году была принята Конвенция о правовом статусе Каспийского моря и правовой статус водоема был определен, теперь на первое место выходит имплементация норм по защите окружающей среды, исполнение реальных мероприятий и повышение их эффективности. В этой связи новым этапом может стать передача части функций, предусмотренных межправительственной конвенцией и возложенных на национальные органы прикаспийских государств, на уровень единой компетентной межпра- 
вительственной организации для повышения их эффективности.

В научном сообществе давно ведется дискуссия о проблематике исполнительных органов государств, исполнения положений конвенции. В соответствии с Рамочной конвенцией формируется национальный орган у каждой стороны, но очевидно, что на данном этапе развитие международного права предполагает более унифицированные подходы. По мнению Н.М. Хурчака, в Рамочную конвенцию 2003 года следует добавить положения о создании в рамках Конференции как главного органа по защите окружающей среды специализированных структур (комитетов, групп) для решения отдельных вопросов. В целях мониторинга и осуществления координации мер по защите окружающей среды Каспия предлагается вместо Комиссии по биоресурсам Каспийского моря, действующей по Соглашению 1992 года, создать Каспийский экологический центр (Protokol o regional'noj gotovnosti.., 2011). Е. С. Анянова рассматривает вопрос о создании прикаспийскими государствами единого, находящегося в совместном ведении координирующего органа для решения экологических проблем Каспийского моря и постоянно действующей службы экологической безопасности и системы экологического мониторинга (Anianova, 2010: 155-156). Считаем данный подход верным, до сих пор в текущих условиях единая межправительственная организация взаимодействия между прикаспийскими государствами не создана, и в контексте современного состояния правового статуса Каспийского моря является важной мерой.

\section{Правовая характеристика и применение концепции комплексного прибрежного управления в отношении российской части побережья Каспийского моря в контексте региональных международно-правовых механизмов охраны окружающей среды}

Прибрежные зоны представляют собой сложный элемент ввиду собственной специфики: в этих районах происходит сосу- ществование различных областей промышленности нескольких государств, ведется добыча полезных ископаемых и сырья, хозяйственная деятельность. Взаимодействия морских территорий и суши очень ощущаются: деятельность на суше приводит, например, к сбросу загрязняющих веществ в водоемы.

Из-за отличий имеющих место в прибрежных зонах видов деятельности возможно столкновение интересов природопользователей на данной территории. В связи с этим возникает необходимость в разработке специального плана по управлению данными районами с учетом экологической, социальной и культурной сторон вопроса.

Проанализировав сложившиеся способы управления Каспийским регионом, можно также сделать вывод о том, что к странам Каспия подходит применение концепции комплексного прибрежного управления. В рамках данной концепции происходит попытка координирования и систематизации деятельности относящихся к одному прибрежному району стран в международноправовой среде. Комплексное управление прибрежной зоной (КУПЗ) - это система управления ресурсами, основанная на комплексном, целостном подходе и интерактивном процессе планирования при решении сложных вопросов управления в прибрежной зоне.

Эта концепция была принята в 1992 году во время саммита Земли в Риоде-Жанейро. Политика в отношении КУПЗ изложена в материалах саммита в рамках Повестки дня на XXI век, глава 17. Европейская комиссия определяет КУПЗ как динамичный, междисциплинарный и повторяющийся процесс для содействия устойчивому управлению прибрежными зонами. Он охватывает полный цикл сбора информации, планирования (в самом широком смысле), принятия решений, управления и мониторинга реализации. КУПЗ использует информированное участие и сотрудничество всех заинтересованных сторон для оценки социальных целей в данном прибрежном районе и для принятия мер по достижению 
этих целей. КУПЗ стремится в долгосрочной перспективе сбалансировать экологические, экономические, социальные, культурные и рекреационные цели в пределах, установленных естественной динамикой. «Интегрированный» в КУПЗ означает интеграцию целей, а также интеграцию множества инструментов, необходимых для достижения этих целей. Это означает интеграцию всех соответствующих областей политики, секторов и уровней управления. Это означает интеграцию наземного и морского компонентов целевой территории как во времени, так и в пространстве.

Не существует глобального международного договора, в котором основное внимание уделяется вопросам прибрежных районов, однако Рамочная конвенция $\mathrm{OOH}$ об изменении климата требует от государств подготовки планов комплексного управления прибрежными зонами. Несколько глобальных договоров касаются конкретно морских проблем, наиболее важными из которых с точки зрения прибрежного управления являются Конвенция ООН по морскому праву и конвенции о загрязнении морской среды, принятые под эгидой Международной морской организации. Несколько других глобальных договоров также должны быть приняты во внимание, потому что они касаются вопросов, важных для комплексного прибрежного управления. К ним относятся договоры, касающиеся:

- биологического разнообразия и сохранения дикой природы и мест обитания диких животных (например, Конвенция о биологическом разнообразии, Рамсарская конвенция о водно-болотных угодьях международного значения и Боннская конвенция о сохранении мигрирующих видов диких животных);

- культурного и природного наследия (Конвенция ЮНЕСКО об охране всемирного культурного и природного наследия 1985 года);

- перемещения и удаления опасных отходов (например, Базельская конвенция 1989 года).

Данный правовой институт еще не закреплен в международном праве, в 1998 году Советом Европы был разработан Модельный закон о защите прибрежных зон ввиду того, что Конвенция ООН по морскому праву 1982 года не включает в сферу действия прибрежную зону, описываемую разработчиками данного института как район встречи суши с океаном, охватывающий как окружающую среду у береговой линии, так и примыкающие прибрежные воды. По мнению профессора А.Н. Вылегжанина, концепция комплексного прибрежного управления имеет перед собой три основные задачи:

1. Гармонизация интересов природопользователей, находящихся в прибрежной зоне.

2. Взаимодействие международных и национальных усилий по предупреждению негативных последствий на водном объекте.

3. Ограничение предпринимательства в районе прибрежной зоны на международно-правовом уровне в целях предупреждения истощения природных ресурсов в прибрежной зоне и защиты окружающей среды (Vylegzhanin, 2002: 307-308).

Европейский парламент и Европейский совет приняли в 2002 году Рекомендацию по комплексному управлению прибрежной зоной, в которой определены принципы рационального планирования и управления прибрежной зоной. Они включают необходимость основывать планирование на надежных и общих знаниях, необходимость рассматривать долгосрочные и межсекторальные перспективы для активного вовлечения заинтересованных сторон и необходимости учитывать как наземные, так и морские компоненты прибрежной зоны (European Parliament \& Council, 2002).

Нет единого универсального инструмента по управлению прибрежными зонами, включающего в себя все необходимые элементы. В отношении каждого региона, в частности Каспийского региона, необходим индивидуальный поход ввиду его экологических особенностей, особенностей правового статуса и расположения. Анализ Тегеранской конвенции и прото- 
колов к ней показывает, что по смыслу указанных нормативно-правовых актов на международно-правовом уровне концепция комплексного прибрежного управления уже внедрена. Так, как было показано выше, ст. 19 Тегеранской конвенции устанавливает целый ряд положений по мониторингу и сбору информации о состоянии прибрежных зон. Принят Московский протокол по загрязнениям, в рамках которого, в сущности, реализуется принцип бассейнового управления, который может быть рассмотрен как элемент концепции комплексного прибрежного управления, так как направлен на координацию деятельности природопользователей, осуществляющих свою хозяйственную деятельность на реках и в море. В рамках Актауского протокола стороны выразили намерение защитить морскую среду Каспийского моря и прибрежные районы от загрязнения нефтью.

Данная концепция нашла свое отражение и на национальном уровне. В 1972 году в США был принят Федеральный закон об управлении прибрежными зонами (Coastal Zone Management Act, 1972). Данный нормативно-правовой акт служит хорошим примером совместного управления и планирования прибрежных районов на федеральном уровне / уровне штата. Закон устанавливает федеральную программу, которая поощряет прибрежные штаты, в том числе вдоль Великих озер, принять программу управления прибрежными зонами в соответствии с минимальными федеральными требованиями. Штаты вынуждены вступать в это добровольное партнерство с федеральным правительством ввиду двух основных стимулов: существенного федерального финансирования и возможности осуществлять определенный контроль за деятельностью федерального правительства в прибрежной зоне посредством положений о «согласованности». С другой стороны, федеральное правительство благодаря этому способствует тому, чтобы штаты уделяли внимание национальным приоритетам, обладая полномочиями утверждать государственные программы и контролировать их реализацию.
Общие требования к программе заключаются в том, что она должна предусматривать управление прибрежными водами и прилегающими прибрежными районами, использование которых оказывает прямое и существенное влияние на прибрежные воды или которые могут быть уязвимы для повышения уровня моря, а также принятие мер для обеспечения надлежащей защиты важных районов, таких как водно-болотные угодья, пляжи, дюны и барьерные острова, которые делают прибрежную зону штатов уникальной или ценной. Во-вторых, программа должна интегрировать в себе три широких спектра деятельности, которые связаны с защитой ресурсов, управлением развитием прибрежных районов и упрощением управленческих процессов. В-третьих, проводимая в отношении прибрежных зон политика должна соответствовать характеру и степени управления, связанным с принятым в данном регионе природопользованием. Наконец, в-четвертых, стандарты, цели, критерии и процедуры, с помощью которых будут приниматься программные решения, должны обеспечивать четкое понимание содержания программы, особенно при определении того, на кого и как повлияет программа.

Специальные требования к программе по управлению прибрежной зоной каждого штата заключаются в том, что такая программа должна включать: а) определение границ прибрежной зоны, на которую распространяется программа; б) определение того, что представляет собой допустимое использование земли и воды, которые оказывают прямое и существенное влияние на прибрежные воды; в) перечень областей, представляющих особый интерес; г) определение средств для осуществления контроля, включая перечень соответствующего законодательства; д) общие рекомендации в отношении приоритетов использования в конкретных областях; е) описание организационной структуры, предлагаемой для реализации программы, включая обязанности и взаимосвязи местных, региональных, государственных, региональных и межгосударственных учреждений в про- 
цессе управления; ж) определение термина «пляж» и процесс планирования для защиты и доступа к общественным пляжам и другим общественным прибрежным районам, имеющим экологическую, рекреационную, историческую, эстетическую, экологическую или культурную ценность; 3) процесс планирования энергетических объектов, которые могут быть расположены в прибрежной зоне или которые могут оказать существенное влияние на прибрежную зону; и) процесс планирования для оценки последствий эрозии береговой линии и изучения способов контроля или уменьшения воздействия эрозии и восстановления районов, пострадавших от неблагоприятного воздействия.

Закон уполномочивает прибрежные штаты выбирать из следующих трех подходов для достижения целей закона: а) осуществление местного самоуправления в соответствии со стандартами, установленными государством, при условии государственного административного контроля и исполнения; б) непосредственное государственное планирование и регулирование водопользования; в) государственный обзор планов и проектов развития, а также правил землепользования и водопользования, подготовленных любым государственным учреждением или частными застройщиками с правом одобрения или несогласия. Все эти методы, адаптированные к местным условиям, обычно объединяются в программу штата по прибрежному управлению. В некоторых штатах были приняты всеобъемлющие законодательные акты по созданию программ с широкими полномочиями по их пересмотру со стороны государственных органов (Калифорния, Южная Каролина). Одни штаты (Северная Каролина, Вашингтон) поощряют децентрализованные планы местного управления, в то время как другие штаты (Флорида и Висконсин) реализуют свои программы через сеть агентств по всему штату. Одним из недостатков системы управления прибрежной зоной в США является исключение сектора рыбного хозяйства и отсутствие морской направленности в программах штатов. Это результат федеративно-штатовых юрисдикционных границ в территориальном море. В соответствии с Федеральным законом права собственности прибрежного государства ограничиваются затопленными землями и ресурсами в зоне, простирающейся на три морских мили от берега. Это ограничение было включено в Закон 1972 года, и, следовательно, морская граница в программах по прибрежному управлению штатов ограничена зоной трех морских миль территориального моря США. Региональные рыбохозяйственные советы регулируют сектор рыболовства в исключительной экономической зоне на 200 миль или в зоне сохранения рыбного промысла. Следовательно, программы прибрежного управления в штатах, как правило, касаются в первую очередь землепользования и имеют тенденцию недооценивать связанные с водой виды использования прибрежной зоны.

В Швеции основу экологического законодательства составляет Экологический кодекс, который вступил в силу 1 января 1999 года. Как цель Кодекса, так и правила рассмотрения соответствуют основным принципам подхода комплексного прибрежного управления. Кроме того, положения Кодекса, касающиеся управления земельными и водными территориями, позволяют признать, что прибрежные районы требуют особой защиты и особого подхода к управлению. Например, Кодекс предусматривает, что зоны должны использоваться для целей, которым они лучше всего подходят с учетом их характера и ситуации, а также существующих потребностей (Jekologicheskij kodeks Shvecii.., 1998). Районы, представляющие особую природную или культурную ценность или особенно подходящие для определенных видов использования (например, для коммерческого рыболовства, аквакультуры или отдыха), должны быть защищены от мер, которые могут нанести ущерб этим ценностям или видам использования, особенно если рассматриваемая ценность или использование относится к национальным интересам. Многие прибрежные районы и архипелаги были защи- 
щены на этой основе как районы, в которых встречаются природные и культурные ценности, представляющие национальный интерес, и, следовательно, туризм и отдых на природе имеют приоритет над другими видами использования этих районов. В Кодексе также содержится конкретное положение о защите берегов моря, внутренних озер и водотоков путем создания береговой охранной зоны (обычно шириной 100 метров), в пределах которой большинство строительных работ запрещено.

Французское законодательство в области прибрежного управления интересно тем, что оно основано на двух отдельных законах, которые вместе могут предположительно охватить всю прибрежную зону. Один закон предписывает правила для схем местного наземного зонирования, а другой - вводит инициированный и санкционированный государством план морского зонирования. В 1979 году были внесены первые поправки, конкретно касающиеся побережья, в общий закон о зонировании и землепользовании (в Кодексе туризма). За этим последовало введение двух наиболее важных правовых документов, регулирующих прибрежную зону Франции. Первый - это закон от 7 января 1983 года, в основном касающийся регулирования морской среды, который ввел систему планов по улучшению и эксплуатации моря. Второй - Закон о побережье (1986 года), который по сути является законом о планировании землепользования. Закон 1983 года - это план, который разбивает зоны прибрежного моря и прилегающих территорий в соответствии с использованием и указывает варианты будущего развития района. Эта концепция была введена законом, который реорганизовал распределение полномочий между территориальными подразделениями во Франции (коммунами, департаментами, регионами и государством). Все документы, касающиеся урбанизации, землепользования и зонирования, должны соответствовать данному закону. Закон о побережье относится в основном к наземным аспектам прибрежной зоны. Он изменяет общие французские законы о зонировании и зем- лепользовании, содержащиеся в Кодексе туризма, чтобы учесть уникальную природу прибрежной зоны.

При подготовке программы органы по планированию землепользования в каждой коммуне обязаны соблюдать следующие национальные принципы:

- Во-первых, необходимо контролировать расширение городов. Это означает, что рост городов в будущем должен осуществляться в соответствии с существующими городскими и провинциальными зонами и в гармонии с окружающей средой. В зонах, прилегающих к берегу, ограниченное расширение городов допускается при условии, что это предусмотрено в программе и оправдывается конфигурацией участка или тем, что строительство или экономическая деятельность зависит от близости воды. В любом случае закон предусматривает запретную зону в 100 метрах от побережья.

- Во-вторых, урбанизированные зоны должны перемежаться с природными территориями.

- Наиболее чувствительные районы (обладающие соответствующими характеристиками) должны быть защищены от урбанизации. В таких зонах допускается только легкое строительство, если это необходимо для управления зоной, для экономического развития или доступа к нему населения.

Одна из проблем французской системы заключается в том, что нормы двух законов ориентированы на регулирование хозяйственной деятельности и охраны окружающей среды в прибрежных зонах на море и на суше соответственно, а соотношение между данным регулированием учитывается в недостаточной степени.

На сегодняшнем этапе важной задачей представляется развитие российского национального законодательства, приведение национальных правовых норм в соответствие с тем уровнем концепции комплексного прибрежного управления, который уже можно констатировать на региональном уровне, в том числе в форме создания специализированных норм об управлении 
прибрежными зонами, с опорой на опыт зарубежных государств. Требуется гибкий подход, так как между государствами существуют большие различия в административном, правовом и культурном контексте, а также уровне зрелости в береговом управлении.

В российском праве отсутствуют единые нормативно-правовые акты по управлению прибрежными зонами. Однако нормы, затрагивающие управление и защиту прибрежных зон, разрозненно закреплены и находят свое отражение в законодательных актах, посвященных защите окружающей среды и охране природных ресурсов. В российском законодательстве не существует определения понятия прибрежной зоны. Рассмотренный выше подробно Водный кодекс Российской Федерации раскрывает лишь понятие «водоохранной зоны», рассматриваемое как земельная составляющая прибрежной зоны.

Для приведения уровня внедрения концепции комплексного прибрежного управления, существующей на национальном уровне, в соответствие с региональным в рамках российского законодательства необходимо выработать законодательное определение прибрежных зон, соединить нормы по управлению морскими территориями и наземной частью прибрежной зоны, выработанные в соответствии с экологическим законодательством и защищающие и ограничивающие интересы природопользователей, нормы по уровню допустимого использования прибрежных зон. При этом требуется учитывать специфику экологического состояния Каспийского моря и особенности хозяйственной деятельности в Каспийском регионе.

\section{Выводы}

В рамках совместных действий прикаспийских государств по защите окружающей среды представляется целесообразным создание компетентной межправительственной организации пяти государств в виде региональной организации сотрудничества по осуществлению мониторинга, контроля, надзора за состоянием полного спектра показателей Каспийского региона, а также для функций оперативного реагирования в случае аварий, загрязнений и прочих инцидентов, которые потенциально могут оказать негативное воздействие на окружающую среду Каспийского моря. Деятельность данной организации может устанавливать взаимодействие между внутренними компетентными органами прикаспийских государств, тем самым упрощая порядок совместного принятия мер по Каспийскому региону, а также централизуя деятельность соответствующих внутренних органов пяти государств. Данная организация при Секретариате Рамочной конвенции может выполнять посредническую роль между сторонами и их компетентными национальными органами по сотрудничеству и мониторингу, выполняя следующие функции:

1. Осуществление сбора данных и информации, подготовка и ведение базы данных о состоянии морской среды и прибрежных районов Каспийского моря касательно его физических, биологических и химических характеристик.

2. Осуществление сбора данных и информации, подготовка и ведение базы данных о поступлении из наземных источников загрязняющих веществ, включая информацию о распределении источников и количестве таких веществ, внесенных в морскую среду и прибрежные районы Каспийского моря.

3. Регулярное проведение общерегиональной оценки состояния морской среды и прибрежных районов Каспийского моря, а также оценки воздействия на окружающую среду Каспийского моря.

4. Принятие всех возможных мер по координированию совместных действий компетентных органов прикаспийских государств по предотвращению, уменьшению и максимально возможной ликвидации последствий инцидентов, вызывающих загрязнение, в том числе загрязнения от разливов нефти.

5. Осуществление связи между сторонами для обмена документацией и оперативного реагирования. 
Проанализировав основную базу регулирования охраны окружающей среды Каспийского моря, в том числе два основных вида загрязнения (разливы нефти и стоки рек), делаем вывод, что концепция прибрежного управления уже нашла свое отражение на уровне международного права, в рамках региональных механизмов охраны окружающей среды Каспийского моря (в частности, внедрен принцип бассейнового управления). На уровне национального законодательства Российской Федерации положения концепции комплексного прибрежного управления могут найти точечное отражение в нормативно-правовых актах, регулирующих сферу охраны окружающей среды Каспийского моря.

По нашему мнению, создание отдельного закона по управлению прибрежными зонами (как минимум в отношении Каспийского региона) могло бы обеспечить приведение уровня внедрения концепции комплексного прибрежного управления на национальном уровне в соответствие с региональным. Анализ опыта зарубежных стран в данной сфере показывает, что такой нормативно-правовой акт должен интегрировать в себе правовые нормы по регулированию хозяйственной и природоохранительной деятельности на территориях, соединяющих участки воды и суши (на сегодняшний день такие нормы в рамках российского законодательства разобщены, институт прибрежной зоны не установлен).

В контексте развития национального регулирования охраны окружающей среды Каспия в логике внедрения концепции комплексного прибрежного управления на региональном уровне важно сфокусировать регулирование на следующих аспектах прибрежного управления:

1. Разработка законодательного определения понятия прибрежной зоны, по меньшей мере, в отношении Каспийского региона.

2. Установление соотношения и интеграция норм, применимых в отношении водных и земельных участков прибреж- ных зон, уже существующих в отдельных нормативно-правовых актах национального законодательства.

3. Установление законодательной защиты от урбанизации наиболее уязвимых участков территорий прибрежных зон.

4. Формирование норм, направленных на установление допустимого уровня вовлечения прибрежных зон в хозяйственную деятельность с целью сохранения и защиты окружающей среды и природных ресурсов.

Каспийское море является уникальным водоемом, нуждающимся в особом правовом регулировании охраны окружающей среды. На уровне национального законодательства в отношении Каспия регуляторами выступают Федеральные законы, постановления Правительства Российской Федерации, региональные нормативноправовые акты.

В Конституции Российской Федерации устанавливается, что принципы и нормы, характерные для международного права, и договоры Российской Федерации с другими государствами являются частью национальной правовой системы. Рамочная конвенция по защите морской среды Каспийского моря 2003 года, именуемая также Тегеранской конвенцией, является одним из ключевых международно-правовых актов в отношении Каспийского региона. Положения Тегеранской конвенции глобально описывают стремление стран-участниц к предотвращению, снижению и контролю загрязнения Каспийского моря.

Одним из наиболее важных вопросов в отношении обеспечения устойчивого развития Каспийского моря представляется вопрос о создании единой компетентной межправительственной организации, обеспечивающей взаимодействие между всеми прикаспийскими государствами. На национально-правовом уровне Российской Федерации следует внедрить нормы о регулировании прибрежных зон для защиты окружающей среды и природных ресурсов российского сектора Каспийского региона. 


\section{Список литературы / References}

Anianova, E.S. (2010). Problemy Kaspiiskogo moria v sovremennom mezhdunarodnom prave [Problems of the Caspian Sea in Modern International Law] (Thesis for Candidate of Sciences). The Institute of State and Law of The Russian Academy of Sciences, Moscow, 223 p.

Borgese, E.M. (1998). The oceanic circle: Governing the seas as a global resource. Tokyo, New York, United Nations University Press, 240 p.

Coastal Zone Management Act of 1972. Available at: https://www.govinfo.gov/content/pkg/STATUTE-86/pdf/STATUTE-86-Pg1280.pdf (Accessed: 17.04.2020).

European Parliament, Council. (2002). Recommendation of the European Parliament and of the Council of 30 May 2002 concerning the implementation of Integrated Coastal Zone Management in Europe. In Official Journal of the European Communities, L 148, 24-27.

Federal'nyj zakon ot 10.01.2002 № 7-FZ «Ob ohrane okruzhajushhej sredy» [Federal Law of 10.01.2002 No. 7-FZ «On Environmental Protection»]. Available at: http://base.garant.ru/12125350/ (Accessed: 10.02.2020).

Federal'nyj zakon ot 31.07.1998 № 155-FZ «O vnutrennih morskih vodah, territorial'nom more i prilezhashhej zone Rossijskoj Federacii» [Federal Law of 31.07.1998 No. 155-FZ «On internal sea waters, the territorial sea and the contiguous zone of the Russian Federation»]. Available at: http://base.garant. ru/12112602/ (Accessed: 10.02.2020).

Federal'nyj zakon ot 23.11.1995 № 174-FZ «Ob jekologicheskoj jekspertize» [Federal Law of 23.11.1995 No. 174-FZ «On Environmental Expertise»]. Available at: http://base.garant.ru/10108595/ (Accessed: 10.02.2020).

Federal'nyj zakon ot 30.12.1995 № 225-FZ «O soglashenijah o razdele produkcii» [Federal Law of 30.12.1995 No. 225-FZ «On Production Sharing Agreements»] Available at: http://base.garant.ru/10105771/ (Accessed: 22.03.2020).

Jekologicheskij kodeks Shvecii 1998 g. [Environmental Code of Sweden 1998]. Available at: https://www.government.se/49b73c/contentassets/be5e4d4ebdb4499f8d6365720ae68724/the-swedish-environmental-code-ds-200061 (Accessed: 19.03.2020).

Ikaev, D.G. (2006). Problemy opredelenija mezhdunarodno-pravovogo statusa Kaspijskogo morja [Problems of Determining the International Legal Status of the Caspian Sea] (Thesis for Candidate of Sciences). Peoples' Friendship University of Russia, Moscow, 203 p.

Interim Secretariat of the Framework Convention for the Protection of the Marine Environment of the Caspian Sea, Project Coordination Management Unit of the "CaspEco" project (2011). Caspian Sea: State of the environment. Available at: http://www.tehranconvention.org/IMG/pdf/Caspian_SoE_Eng_fin. pdf (accessed 12 February 2020).

Janusz-Pawletta, B. (2015). The Legal Status of the Caspian Sea. Berlin, Heidelberg, Springer Berlin Heidelberg, 176 p. DOI: 10.1007/978-3-662-44730-7

Joyner, C., Walters, K.Z. (2006). The Caspian Conundrum: Reflections on the Interplay Between Law, the Environment and Geopolitics. In The International Journal of Marine and Coastal Law, 21(2), $173-216$. DOI: $10.1163 / 157180806777973068$

Khaustov, D.V. (2012). Aktual'nye problemy pravovogo regulirovaniia ekologicheskoi ekspertizy na sovremennom etape [Topical issues of legal regulation of environmental expertise at the contemporary stage]. In Ekologicheskoe Pravo [Environmental Law], (4), 42-48.

Khurchak, N.M. (2006). Mezhdunarodno-pravovoi status Kaspiiskogo moria i mezhdunarodnoe ekonomicheskoe sotrudnichestvo prikaspiiskikh gosudarstv [International legal status of the Caspian Sea and international economic cooperation of the Caspian states] (Thesis for Candidate of Sciences). Russian Foreign Trade Academy, Moscow, 141 p.

Kodeks Rossijskoj Federacii ob administrativnyh pravonarushenijah ot 30.12.2001 № 195-FZ [The Code of the Russian Federation on Administrative Offenses of 30.12.2001 No. 195-FZ]. In Sobranie zakonodatel'stva RF [Collected Legislation of the Russian Federation], 07.01.2002, No. 1 (part 1), 1. Available at: http://base.garant.ru/12125267/ (Accessed: 12.04.2020). 
Konvencija o pravovom statuse Kaspijskogo morja 2018 goda [Convention on the Legal Status of the Caspian Sea]. Available at: http://kremlin.ru/supplement/5328 (Accessed: 10.02.2020).

Konstitucija Rossijskoj Federacii (prinjata vsenarodnym golosovaniem 12.12.1993) (s popravkami) [Constitution of the Russian Federation (adopted by popular vote 12.12.1993) (as amended)]. Available at: https://constitution.garant.ru/ (Accessed: 10.02.2020).

Maximov, A.M. (2015). Sub"ekt prestupleniia protiv zhivotnogo mira (st. 256, 257, 258, 2581, 259 UK RF): Tselesoobraznost' priznaniia takovym iuridicheskogo litsa (argumenty za i protiv) [Subject of a crime against fauna (articles 256, 257, 258, 2581, 259 of the RF criminal code): Expediency of recognizing as such a legal entity (pros and cons)]. In Rossiiskii Sledovatel' [Russian Investigator], (18), 24-27.

Postanovleniem Arbitrazhnogo suda Severo-Kavkazskogo okruga ot 11.07.2016 № F08-4192/2016 po delu № A15-3070/2015 reshenie Arbitrazhnogo suda Respubliki Dagestan ot 15.12.2015 [Resolution of the Arbitration Court of the North Caucasus District dated July 11, 2016 No. F08-4192 / 2016 in case No. A15-3070 / 2015, the decision of the Arbitration Court of the Republic of Dagestan dated December $15,2015]$

Postanovlenie Pravitel'stva RF ot 16 ijunja 2004 g. N 282 «Ob utverzhdenii Polozhenija o Federal'nom agentstve vodnyh resursov». [Resolution of the Government of the Russian Federation of June 16, $2004 \mathrm{~N}$ 282 "On approval of the Regulation on the Federal Agency for Water Resources"]. Available at: http://base. garant.ru/12135833/ (Accessed: 18.03.2020).

Postanovlenie FAS Severo-Kavkazskogo okruga ot 22.11.2007 № F08-7602/07 po delu № A15651/2007. [Resolution of the Federal Antimonopoly Service of the North Caucasus District of November 22, 2007 No. F08-7602 / 07 in case No. A15-651 / 2007].

Prikaz FSB Rossii ot 25.12.2012 № 675 «Ob utverzhdenii Administrativnogo reglamenta Federal’noj sluzhby bezopasnosti Rossijskoj Federacii po ispolneniju gosudarstvennoj funkcii po osushhestvleniju gosudarstvennogo kontrolja $\mathrm{v}$ sfere ohrany morskih biologicheskih resursov». [Order of the FSB of Russia dated December 25, 2012 No. 675 "On approval of the Administrative Regulations of the Federal Security Service of the Russian Federation for the execution of the state function of exercising state control in the field of the protection of marine biological resources."]. Available at: http://base.garant.ru/57404395/ (Accessed: 22.03.2020).

Protokol o regional'noj gotovnosti, reagirovanii i sotrudnichestve v sluchae incidentov, vyzyvajushhih zagrjaznenie neft'ju ot 12 avgusta 2011 goda. [Protocol on Regional Preparedness, Response and Cooperation in the Event of Oil Pollution Incidents of 12 August 2011]. Available at: http://www.tehranconvention. org/IMG/pdf/Aktau_Protocol.pdf (Accessed: 22.03.2020).

Protokol po zashhite Kaspijskogo morja ot zagrjaznenija iz nazemnyh istochnikov i v rezul'tate osushhestvljaemyh na sushe vidov dejatel'nosti ot 12 dekabrja 2012 goda [Protocol on the Protection of the Caspian Sea against Pollution from Land-Based Sources and from Land-Based Activities of 12 December 2012]. Available at:http://www.tehranconvention.org/IMG/pdf/Protocol_on_Pollution_from_Land_ Based_Sources_and_Activities.pdf (Accessed: 12.04.2020).

Protokol po zashhite Kaspijskogo morja ot zagrjaznenija iz nazemnyh istochnikov i v rezul'tate osushestvljaemyh na sushe vidov dejatel'nosti («Moskovskij Protokol») ot 12 dekabrja 2012 goda [Protocol on the Protection of the Caspian Sea from Pollution from Land-Based Sources and from Land-Based Activities ("Moscow Protocol") of December 12, 2012]. Available at: http://www.tehranconvention.org/IMG/pdf/Protocol_on_Pollution_from_Land_Based_Sources_and_Activities.pdf (Accessed: 05.04.2020).

Protokol o regional'noj gotovnosti, reagirovanii i sotrudnichestve v sluchae incidentov, vyzyvajushhih zagrjaznenie neft'ju («Aktauskij protokol») ot 12 avgusta 2011 goda [Protocol on Regional Preparedness, Response and Cooperation in the Event of Oil Pollution Incidents ("Aktau Protocol") dated August 12, 2011]. Available at: http://www.tehranconvention.org/IMG/pdf/Aktau_Protocol.pdf (Accessed: 05.04.2020).

Protokol o regional'noj gotovnosti, reagirovanii i sotrudnichestve v sluchae incidentov, vyzyvajushhih zagrjaznenie neft'ju ot 12 avgusta 2011 goda [Protocol on Regional Preparedness, Response and Cooperation in the Event of Oil Pollution Incidents of 12 August 2011]. Available at: http://www.tehranconvention. org/IMG/pdf/Aktau_Protocol.pdf (Accessed: 17.04.2020). 
Ramochnaja konvencija po zashhite morskoj sredy Kaspijskogo morja 2003 goda [Framework Convention for the Protection of the Marine Environment of the Caspian Sea 2003]. Available at: http://www. tehranconvention.org/IMG/pdf/Tehran_Convention_text_final_pdf.pdf (Accessed: 03.03.2020).

Rasporjazhenie Pravitel'stva RF ot 07.06.2014 № 987-r «Ob utverzhdenii plana kompleksnogo stimulirovanija osvoenija mestorozhdenij uglevodorodnogo syr'ja na kontinental'nom shel'fe Rossijskoj Federacii i v rossijskoj chasti dna Kaspijskogo morja» [Order of the Government of the Russian Federation of 07.06.2014 No. 987-r "On approval of the plan for comprehensive stimulation of the development of hydrocarbon deposits on the continental shelf of the Russian Federation and in the Russian part of the bottom of the Caspian Sea"]. Available at: http://www.szrf.ru/szrf/doc.phtml?nb=100\&issid=1002014024000\&do$\mathrm{cid}=80$ (Accessed: 22.03.2020).

Saparov, S.M. (2016). Pravovoe regulirovanie obespechenija jekologicheskoj bezopasnosti pri nedropol'zovanii v Kaspijskom more [Legal regulation of ensuring environmental safety during subsoil use in the Caspian Sea] (Thesis for Candidate of Sciences). National University of Oil and Gas «Gubkin University» Moscow, $145 \mathrm{p}$.

Suleymanova, S.T. (2016). Evoliutsiia tselei nakazaniia v ugolovnom prave Rossii i Kanady [Evolution of the Purposes of Punishment in Criminal Law of Russia and Canada]. In Lex Russica, (7), 103-115 DOI: 10.17803/1729-5920.2016.116.7.103-115

Ugolovnyj kodeks Rossijskoj Federacii ot 13.06.1996 № 63-FZ [The Criminal Code of the Russian Federation dated 13.06.1996 No. 63-FZ]. Available at: http://base.garant.ru/10108000/ (Accessed: 03.03.2020).

UNEP (2020). Caspian Sea: The Tehran Convention. Available at: https://www.unenvironment.org/ explore-topics/oceans-seas/what-we-do/working-regional-seas/regional-seas-programmes/caspian-sea (accessed 30 March 2020).

UNEP, UNDP, OSCE, NATO (2005). Environment and security: Transforming risks into cooperation; Central Asia, Ferghana, Osh, Khujand area. Geneva, UNEP, 53 p.

Vylegzhanin, A.N. (2002). Mezhdunarodno-pravovye osnovy prirodoresursnoi deiatel'nosti gosudarstv v Mirovom okeane [International Legal Basis of Natural Resources Activity of States in the World Ocean] (Doctoral thesis). Diplomatic Academy of the Ministry of Foreign Affairs of the Russian Federation, Moscow, 349 p.

Vylegzhanin, A.N., Andreeva, E.E., Speranskaya, L.V. (2002). K uchetu mezhdunarodno-pravovykh nachal ekosistemnogo upravleniia prirodnymi resursami Kaspiia [Towards the accounting of international legal principles of the ecosystem management of natural resources of the Caspian]. In Vestnik Kaspiia [Herald of the Caspian Sea], (6), 65-69.

Zhochkina, I.N. (2015). Problemy teorii ekologicheskogo prava [Rules of law in the mechanism of legal regulation of regional state environmental management]. In Ekologicheskoe Pravo [Environmental Law], (5), 6-13.

Zonn, I.S. (2005). Environmental Issues of the Caspian. In The Caspian Sea Environment, 5P, 223 242. DOI: $10.1007 / 698 \_5 \_012$ 